\title{
Evolving Ownership and the Capital Structure Regime in Japan
}

\section{Wali Ullah* and Shahzadah Nayyar Jehan**}

\begin{abstract}
This study is an attempt to investigate the implications of changes in ownership structure and control transfer in the Japanese corporate market-a trend attributed mainly to the government's increasing liberalization policies during the 1990s. Our results show that firms characterized by more concentrated ownership are likely to prefer less debt as ownership concentration reduces the extent of agency costs between managers and shareholders and facilitates equity issues. The main bank system enables corporations to obtain funds easily through the debt market. Additionally, unwinding cross-shareholding between banks and corporations provides impetus for investment in relatively risky projects. The ownership pattern of private and foreign individuals is consistently associated with a shift from bank debt to equity financing. Moreover, managerial ownership reduces the risk of wasting free cash flows. Managers make fewer decisions that may have a negative effect on the firm's value because the part of costs that they will absorb as shareholders increases as their share of capital rises. The results suggest that government ownership is associated with more pressure on management and enforces the efficient use of cash flows. Changes in ultimate ownership will likely lead to major asset and capital restructuring in the coming years.
\end{abstract}

Keywords: Corporate governance, change in control, capital structure, financial reforms.

JEL classification: G15, G32, G34, G38.

\section{Introduction}

Until the 1990s, indirect bank financing was the dominant practice among Japanese companies and had long shaped their financial structure. Their ownership structure was characterized by cross-shareholdings with banks and the corporate sector in which they operated. This type of

\footnotetext{
* The author is a postdoctoral research fellow at the Graduate School of Economics and Management, Tohoku University, Japan; he can be contacted at wali76@yahoo.com.

** The author is an associate professor at the Centre for International Education, Tohoku University, Japan. The authors would like to thank the editor and anonymous referee for their valuable comments on an earlier draft of this paper.
} 
shareholding pattern was not only associated with ownership structure, but it also had an impact on firms' financial choices for fund raising. This period resulted in close long-term business ties between firms and banks. According to a survey conducted by the Fuji Research Institute (1993), more than 90 percent of large listed corporations had one or two "main banks" (on average, 1.6) prior to the change in financial practices. ${ }^{1}$

This cross-holding pattern, in turn, formed the basis of conventional Japanese corporate governance, where firms were heavily financed by bank borrowing and banks were represented on the firms' corporate boards. While such close bank-firm ties increased the availability of capital for borrowing firms, they did not necessarily lead to higher profitability or growth (Weinstein \& Yafeh, 1998). ${ }^{2}$ Instead, they increased the cost of capital for firms. Banks involuntarily ended up extracting significant rents from their client firms through interest payments while inhibiting the latter's growth through conservative investment policies.

In the late 1980s, the age-old system hit a snag due to significant changes in the country's economic conditions (see Annex). In the first half of the 1990s, various regulations and restrictions introduced during the high-growth period were gradually relaxed or removed. During the decade, the process of dramatic deregulation and liberalization made corporate borrowing and raising equity in both domestic and foreign capital markets much easier. The liberalization of financial markets and easier access to capital markets reduced Japanese banks' market power. Access to foreign markets and more liberal domestic capital markets reduced the main banks' influence over firms' policies.

The availability of alternative sources of financing and the decline in the firm-main bank relationship led to a drastic change in firms' ownership structure. Increasingly, cross-held shares in companies that were once held for the purpose of maintaining a main bank's relationship with a firm were sold. Corporate governance structure and control,

\footnotetext{
${ }^{1}$ A main bank relationship - the relationship between a firm and a bank-is typically characterized by the following: (i) the firm continuously accounts for a large (or the largest) volume of borrowing over a long period; (ii) the bank is a main shareholder in the firm; (iii) the bank carries out a variety of banking and other transactions with the firm, such as handling foreign exchange and undertaking the trustee function of corporate bonds; (iv) the bank maintains a close personal relationship by dispatching executives to the client firm; and (v) although the bank does not intervene in the management of the client firm, as long as the firm is making reasonable profits, the bank often rescues the client firm when the latter is in financial distress, provided that it is judged as being eventually viable.

${ }^{2}$ Prowse (1990) suggests that, because large shareholders are also larger debt holders, they may preclude policies that attempt to transfer wealth from debt holders to shareholders.
} 
therefore, changed significantly during this period. The main bank system was gradually replaced by the increased role of market investors and the capital market in generating long-term capital.

In this study, our main focus is the impact of governance structure and change in ownership on firms' financial choices and borrowing patterns - a change apparently necessitated by the legal and corporate reforms that took place in the post-"bubble" period Japan. In this context, we aim to understand the following:

- How companies determine their overall financial strategies

- Why they choose a particular mix of financial instruments

- Why they choose to limit borrowing or set up spare borrowing capacity

- The association between corporate governance structure and changes in ultimate ownership

Exploring these questions opens up the possibility of investigating:

- The specific factors or characteristics that encourage firms to choose different financial strategies

- Whether the structure of equity ownership can help explain crosssectional variations in capital structure in the case of Japanese firms.

The rest of the paper is organized as follows. Section 2 describes methodological issues pertaining to variable construction and modeling. Section 3 presents our empirical results. Section 4 assesses the robustness of the results and Section 5 presents some concluding remarks.

\section{Methodological Issues: Variables, Modeling, and Sample}

The way in which a firm finances its operations through some combination of common and preferred stock, either with retained earnings or with bonds and loans, is known as "capital structure." Generally, firms use either debt or equity to finance their investments. However, within the broad categories of debt and equity there exists a variety of financing instruments that firms can use. Firms also have different options for raising equity. Their choices can range from the owner's wealth to venture capital to private equity, although issuing common stock and warrants are the most common ways of raising equity. Regarding debt, the number of alternatives available to firms has increased significantly over the last two 
decades (Bauer, 2004). The conventional choices were bank debt and corporate bonds, but in recent years there have been numerous innovations in this field, especially in the design of corporate bonds.

Although a firm can use any combination of sources, it should use one that maximizes its market value and, in turn, shareholders' wealth. ${ }^{3}$ "Optimal capital structure" refers to that combination of sources of financing that maximizes the firm's market value. The literature on capital structure focuses mainly on whether or not corporate financing decisions matters at all. If financing decisions were completely irrelevant, then actual capital structures should vary randomly from firm to firm and industry to industry. However, this is not what the empirical evidence suggests.

This section examines various ways to measure capital structure and its empirical relevance. This is followed by a discussion on ownership structure and changes in ultimate control. Finally, the section presents other relevant independent variables, a model specification, and sample description.

\subsection{Capital Structure}

Two broad measures of capital structure are commonly used-one based on book value and the other on market value-and both have their strengths and weaknesses. Accordingly, we compute two measures of capital structure in this study. The book value measure (BLEV) is defined as the ratio of the book value of total debt to the total book value of debt and equity, for instance, how the firm has been financed in the past and thus the relative claims of equity and debt over firm value (Jensen \& Meckling, 1976; Myers, 1977). Here, the relevant measure is probably the amount of total book value of debt to capital. MacKay and Philips (2005) point out that the use of book value can be justified on the grounds that financial managers tend to focus on this value when designing financial structures. Barclay and Clifford (1995) justify its use on the grounds that there may be a spurious relationship between the market value measure and Tobin's q ratio (TQR).

Welch (2004) argues, however, that the market value measure of capital structure significantly explains stock returns. For this measure (denoted as MLEV), we follow Fama and French (2005) and Welch (2004),

\footnotetext{
${ }^{3}$ Profit maximization, which is the firm's ultimate goal, leads to the maximization of shareholders' wealth. More precisely, an increase in the firm's after-tax income yields higher dividend payments, which, in turn, maximizes the market value of the firm.
} 
and compute it as the ratio of book value of total debt to the book value of debt and the market value of common equity.

\subsection{Corporate Ownership Structure}

In terms of explanatory variables, the ultimate ownership structure of firms is classified into six distinct categories of shareholders.

Financial institutions, including banks and insurance companies, usually have business dealings such as lending, insurance sales, and other financial transactions, with firms in which they hold shares (Charkham, 1994). Affiliated firms constitute another class of investor, commonly depicted as being a stable shareholder (Gerlach, 1992). These companies are the business partners-either suppliers or customers-of other firms with which they have cross-shareholding arrangements. These affiliated companies hold multiple interests in these firms (Lincoln, Gerlach, \& Ahmadjian, 1996). The impact of these investors is evaluated by the percentage of total outstanding shares held by financial institutions (BKSH) and affiliated companies (NBKSH).

Two classes of investors, i.e., foreign shareholders and domestic private individuals, are considered representative market investors as they are interested in maximizing their current profits rather than developing ongoing business ties with the firms in which they own shares (Inoue, 1999; Yasui, 1999). The percentage of outstanding shares held by foreign investors (FRGN) and domestic private individuals (PRVT) are used to evaluate the importance of market investors.

The other two classes include the percentage shareholding of the government (GOVT) and that of internal investors such as directors and others (INSIDE).

\subsection{Change in Ultimate Ownership}

Identifying the ultimate owner of and change in control for each firm involves two steps. First, we identify the firm's ultimate owner using the criterion of percentage shareholding. A particular corporate entity as described above is considered the ultimate owner if it owns 50 percent or more of the firm's total outstanding shares. If the shareholding is split and none of the six categories (financial institutions, nonfinancial corporations, foreign individuals, domestic private individuals, the government, and insiders) holds more than 50 percent of the shares, then an ultimate owner does not exist and the ownership of the firm is considered to be diverse. 
In the next step, we identify changes in ultimate share ownership by analyzing the percentage change in the shareholding over the sample period for each individual category. Changes in ultimate ownership are measured when the percentage shareholding of a particular group changes from less than 50 percent in the previous period to 50 percent or more in the next period. This is recorded as a change in ultimate ownership (denoted as UCT).

Regarding the various transfers of control, all ownership transfers are grouped into one of four categories: financial (FIT), nonfinancial (NFIT), private individual (PFIT), and diverse transfers. The definition of leverage, ownership structure, change in control, and various other control variables that are likely to affect the firm's capital structure decision are presented in Table 1.

\subsection{Control Variables}

Given our objective in this study, we focus broadly on the relationship between the firm's leverage and ultimate ownership. However, it is necessary to take into account other control variables that might affect the firm's financial choices in order to avoid specification errors in the econometric model. Therefore, various firm-level financial ratios are included in the estimated model as control variables.

The size of a firm is included to account for the potential economies of scale and scope accruing to large firms. Size is an important determinant of capital structure as large firms are more likely to be debt-financed than their smaller counterparts. Large companies are more geospatially diversified and have more stable cash flows, which reduces the risk of the debt they hold. Additionally, they enjoy economies of scale when issuing securities to raise funds; smaller firms are likely to face higher costs when obtaining external funds because of information asymmetries.

We use the natural logarithm of total assets as the measure of firm size (SIZE) and expect it to have a positive impact on the leverage ratio. Profitability as a measure of the return on assets (ROA) has a negative relationship with leverage because firms usually prefer to finance their operations using internal funds rather than debt. Furthermore, the shares of profitable firms take on a high value in the stock market due to the higher dividends earned. Therefore, profitable firms may find it easy to raise funds by issuing equity. We therefore expect a negative relationship between ROA, as measured by the ratio of earnings before interest and tax (EBIT) to total assets, and the leverage ratio. 
Firms that expect high future growth should use more retained earnings and equity rather than debt financing. An improvement in a firm's growth opportunities leads to an increase in the agency cost of debt, which further reduces the level of debt financing (Booth, Aivazian, Demirguc-Kunt, \& Maksimovic, 2001). The firm's growth is measured by the TQR.

Greater volatility in the firm's earning stream leads to higher business risk, and lenders may be reluctant to provide loans. If the firm's earnings are volatile for seasonal or cyclical reasons or due to resource mismanagement, then they will have to pay an extra premium for debt financing. Moreover, such firms are likely to face difficulties in raising external funds because of their unstable cash flows and higher implied earnings volatility. In this study, the risk of the firm (RISK) is measured by the variability of the last ten year's earnings, and we expect it to have a negative impact on the debt ratio. 4

Tangible assets consist mainly of fixed assets. Asset tangibility represents the firm's asset structure and has a direct impact on its capital structure choice. The value of a firm's tangible assets (TANG) is measured as the ratio of fixed assets to total assets, and is used as a proxy for collateral. In a world of asymmetric information, the firm's tangible fixed assets can often serve as collateral to lower the risk of lenders who undertake the agency cost of debt. Therefore, firms with a greater proportion of fixed assets tend to have a higher debt ratio.

Corporate income tax makes debt financing more advantageous than equity financing because interest expenses are tax deductible, lowering the effective cost of debt. The corporate income tax rate has long been identified as a potential determinant of the capital structure decision. Firms prefer to have more debt than equity because of the tax shield on interest. Miller (1977) finds a positive relationship between the corporate income tax rate and firm leverage. In this study, we use the ratio of tax paid by the firm to EBIT as a proxy for the tax shield benefits of debt (TAX) and expect a positive relationship.

The quick ratio is defined as the ratio of the book value of current assets after subtracting the book value of inventories to current liabilities. It captures the magnitude of assets that the company can transform into cash

\footnotetext{
${ }^{4}$ The risk of each firm is calculated as the standard deviation of the firm's earnings using the past ten years' data. A rolling window of size 10 is employed to calculate the standard deviation using the EBIT data for 1982-2009.
} 
within a short period of time relative to what it owes in the short term. The more liquid the firm, the less it will rely on debt. Therefore, according to the pecking order theory, there should be a negative relationship between liquidity and internally generated cash flows and leverage. In this study, we use the quick ratio as a proxy for the firm's liquidity position (LIQR) and expect it to have a negative impact on leverage.

Finally, we include 29 industry dummy variables to control for systematic differences in leverage across industries due to differences in systematic risk and unequal possession of fixed assets. Industries are classified into 30 economic groups based on the classification adopted by the Tokyo Stock Exchange.

Table 1: Definition of variables

\begin{tabular}{|c|c|c|}
\hline Variable & Description & Construction \\
\hline BLEV & $\begin{array}{l}\text { Proxy for firm capital } \\
\text { structure }\end{array}$ & $\begin{array}{l}\text { Leverage based on the book value; ratio } \\
\text { of the book value of total debt to the } \\
\text { total book value of debt and equity. }\end{array}$ \\
\hline MLEV & $\begin{array}{l}\text { Proxy for firm capital } \\
\text { structure }\end{array}$ & $\begin{array}{l}\text { Leverage based on the market value; } \\
\text { ratio of the book value of total debt to } \\
\text { the book value of debt and market } \\
\text { value of common equity. }\end{array}$ \\
\hline BKSH & $\begin{array}{l}\text { Indicator of governance } \\
\text { structure }\end{array}$ & $\begin{array}{l}\text { Financial institutions share ownership; } \\
\text { percentage ratio of shareholding by } \\
\text { financial institutions. }\end{array}$ \\
\hline NBKSH & $\begin{array}{l}\text { Indicator of governance } \\
\text { structure }\end{array}$ & $\begin{array}{l}\text { Nonfinancial institutions share } \\
\text { ownership; percentage ratio of } \\
\text { shareholding by nonfinancial } \\
\text { institutions. }\end{array}$ \\
\hline PRVT & $\begin{array}{l}\text { Indicator of governance } \\
\text { structure }\end{array}$ & $\begin{array}{l}\text { Private individuals share ownership; } \\
\text { percentage ratio of shareholding by } \\
\text { domestic private individuals. }\end{array}$ \\
\hline FRGN & $\begin{array}{l}\text { Indicator of governance } \\
\text { structure }\end{array}$ & $\begin{array}{l}\text { Foreign institutions and individuals } \\
\text { share ownership; percentage ratio of } \\
\text { shareholding by foreign institutions } \\
\text { and individuals. }\end{array}$ \\
\hline INSIDE & $\begin{array}{l}\text { Indicator of governance } \\
\text { structure }\end{array}$ & $\begin{array}{l}\text { Inside share ownership; percentage } \\
\text { ratio of shareholding by insiders such } \\
\text { as directors and other employees. }\end{array}$ \\
\hline GOVT & $\begin{array}{l}\text { Indicator of governance } \\
\text { structure }\end{array}$ & $\begin{array}{l}\text { Government share ownership; } \\
\text { percentage ratio of shareholding by the } \\
\text { government and state-owned agencies. }\end{array}$ \\
\hline
\end{tabular}




\begin{tabular}{|c|c|c|}
\hline Variable & Description & Construction \\
\hline $\mathrm{HI}$ & $\begin{array}{l}\text { Proxy for ownership } \\
\text { concentration }\end{array}$ & $\begin{array}{l}\text { Herfindahl index }(\mathrm{HI})=\sum_{j=1}^{m} X_{j}^{2} \text { as } X_{j} \\
\text { is the proportion of shares held by the } \\
\text { top } 10 \text { largest shareholders in a } \\
\text { particular firm. }\end{array}$ \\
\hline UCT & $\begin{array}{l}\text { Indicator of change in } \\
\text { ultimate control }\end{array}$ & $\begin{array}{l}\text { Change in ultimate ownership; dummy } \\
\text { variable }=1 \text { if ultimate ownership } \\
\text { changes in a particular year and } 0 \\
\text { otherwise. }\end{array}$ \\
\hline FIT & $\begin{array}{l}\text { Indicator of transfer of } \\
\text { ultimate control to financial } \\
\text { institutions }\end{array}$ & $\begin{array}{l}\text { Dummy variable }=1 \text { if the ultimate } \\
\text { transfer is to financial institutions such } \\
\text { as banks, and } 0 \text { otherwise. }\end{array}$ \\
\hline NFIT & $\begin{array}{l}\text { Indicator of transfer of } \\
\text { ultimate control to } \\
\text { nonfinancial institutions }\end{array}$ & $\begin{array}{l}\text { Dummy variable }=1 \text { if the ultimate } \\
\text { transfer is to nonfinancial institutions } \\
\text { such as other affiliate firms and } 0 \\
\text { otherwise. }\end{array}$ \\
\hline PFIT & $\begin{array}{l}\text { Indicator of transfer of ultimate } \\
\text { control to private individuals } \\
\text { or foreign corporations }\end{array}$ & $\begin{array}{l}\text { Dummy variable }=1 \text { if the ultimate } \\
\text { transfer is to private individuals or } \\
\text { foreign corporations and } 0 \text { otherwise. }\end{array}$ \\
\hline SIZE & Proxy for firm size & $\begin{array}{l}\text { Natural logarithm of the book value of } \\
\text { total assets. }\end{array}$ \\
\hline ROA & Proxy for firm profitability & $\begin{array}{l}\text { Return on assets; ratio of EBIT to total } \\
\text { assets. }\end{array}$ \\
\hline TQR & Proxy for firm growth & $\begin{array}{l}\text { Tobin's q ratio; ratio of the market value } \\
\text { of equity and the book value of debt to } \\
\text { the book value of total assets; shows the } \\
\text { replacement cost of total assets. }\end{array}$ \\
\hline Risk & Proxy for firm risk & $\begin{array}{l}\text { Earnings variability over the last } 10 \\
\text { years; calculated as the standard } \\
\text { deviation of the last ten years' EBIT. }\end{array}$ \\
\hline TANG & Proxy for firm collateral value & $\begin{array}{l}\text { Ratio of the book value of fixed assets } \\
\text { to the book value of total assets. }\end{array}$ \\
\hline TAX & $\begin{array}{l}\text { Proxy for tax shield benefits } \\
\text { on interest }\end{array}$ & $\begin{array}{l}\text { Ratio of annual corporate tax paid to } \\
\text { EBIT. }\end{array}$ \\
\hline LIQR & Proxy for firm liquidity & $\begin{array}{l}\text { Quick ratio; ratio of the book value of } \\
\text { current assets less inventories to the } \\
\text { book value of current liabilities. }\end{array}$ \\
\hline
\end{tabular}

Note: The table defines all the variables used in our empirical analysis.

There are several reasons for thinking that the industry in which a firm operates will have a significant effect on its capital structure. Significant differences exist across industries, which influence the capital structure of firms in a certain industry. Some industries may require heavy investment 
in fixed assets, which is a significant variable in the determination of capital structure because fixed assets are closely related to the firm's collateral value. Some industries may carry a high cost of bankruptcy and financial distress. Heavy industries, such as construction, chemicals, electrical goods, engineering, and textiles, are likely to have higher leverage than other industries. Small industries, such as transportation, cement, and food and beverages, are likely to have low debt ratios. Tax structures and subsidies also vary significantly across industries, suggesting that there will be significant differences in leverage across industries.

\subsection{Model Specification}

The objective is to assess the impact of ownership structure and change in ultimate ownership on financing behavior at various points in time. The model needs to be dynamic to enable us to compare the state of capital structure at the time of change in control and after the change in control. We will also compare transfers to various corporate entities, such as financial institutions, other affiliated corporation, and private individuals.

The most important consideration in developing such a model is to separate the impact of ownership and change in control from other factors that might influence capital structure. This can be achieved through panel estimations and by including the lag of the dependent variable as one of the right-hand side regressors. With this lagged dependent variable, any measured influence on financing behavior is conditioned on the entire history of the right-hand side variables. In the econometric literature and in the context of panel data, such models are usually referred to as dynamic panel data models and are written as follows:

$y_{i t}=\sum_{j=1}^{m} \gamma_{j} y_{i, t-j}+x_{i t}^{\prime} \beta+\alpha_{i}+\lambda_{t}+\varepsilon_{i t} i=1,2, \ldots \ldots N, \mathrm{t}=1,2, \ldots \ldots T$

The $\lambda$ and $\beta$ are parameters to be estimated; $x_{i t}$ is a $(k \times 1)$ vector of strictly exogenous covariates; $\alpha_{i}$ and $\lambda_{t}$ are the unobservable individual and time-specific effects, respectively; and $\varepsilon_{i t}$ is the independent identically distributed (iid) error term with a zero conditional mean and variancecovariance matrix $\Omega$.

Standard panel models, such as fixed-effects and random-effects models, are biased and inconsistent in this case as the lagged dependent variable is correlated with the error term $\varepsilon_{i t}$. This inconsistency persists even when no autocorrelation in the error term is assumed. The general 
approach to estimating such a model relies on Arellano and Bond (1991), who suggest using a generalized method of moments (GMM) estimator and instrumental variables technique. GMM uses the data in first-differenced form, which distributes the underlying heterogeneity among the various cross-sectional units. ${ }^{5}$ Accordingly, equation (1) can be written as:

$y_{i t}-y_{i, t-1}=\sum_{j, l=1, j \neq l}^{m} \gamma_{j}\left(y_{i, t-j}-y_{i, t-l}\right)+\left(x_{i t}-x_{i, t-1}\right) \beta+\lambda_{t-1}+\left(\varepsilon_{i t}-\varepsilon_{i, t-1}\right)$

By taking the first difference, the lagged differences of the dependent variable on the right-hand side of the equation are no longer correlated with the $\left(\varepsilon_{i t}-\varepsilon_{i, t-1}\right)$ term. Equation (2) can be estimated using $y_{i, t-l}$ as an instrument for $\left(y_{i, t-j}-y_{i, t-l}\right)$. Although Arellano and Bond (1991) suggest using additional lags of the dependent variable as instruments to enable even more efficient estimation, doing so can lead to the over-identification of the model. They show that GMM provides a consistent estimator if the underlying assumption of no second-order autocorrelation in the differenced residuals is fulfilled. The first-order autocorrelation in residuals from equation (2) does not imply inconsistency in the estimated parameters. Arellano and Bond also suggest applying a specification test to check for over-identification ( $j$-statistics) in the model and a test for second-order autocorrelation.

In estimating the impact of ownership structure, we estimate the following model using GMM:

$$
\begin{aligned}
& y_{i t}=\sum_{j=1}^{2} \gamma_{j}\left(y_{i, t-j}\right)+\left(G O V_{i, t-1}\right) \psi+\delta_{1} S I Z E_{i t}+\delta_{2} R O A_{i t}+\delta_{3} T Q R_{i t}+\delta_{4} R I S K_{i t} \\
& +\delta_{5} T^{2} A N G_{i t}+\delta_{6} T A X_{i t}+\delta_{7} L I Q R_{i t}+\delta_{8} H I_{i t}+\sum_{p=1}^{29} \phi_{p} D U M_{i p}+\alpha_{i}+\lambda_{t}+\varepsilon_{i t}
\end{aligned}
$$

\footnotetext{
${ }^{5}$ By using GMM, one is better able to control for the effects of missing or unobserved variables. Specifically, including the lag of the dependent variable as an explanatory variable in the estimated equation enables us to capture the effects of omitted variables. These effects are driven by either individual time-invariant variables or period individual-invariant variables. Individual time-invariant variables are the same for given cross-sectional units over time but vary across cross-sectional units (intangible assets, managerial skill). Period individual-invariant variables are the same for all crosssectional units at a given time but vary over time (macroeconomic scenario). All these omitted variables may be correlated with the independent variable. Hence, the GMM technique overcomes possible heterogeneity and omitted variable problems, which often arise with cross-sectional analysis. We also incorporate a year dummy to control for unobserved macroeconomic effects.
} 
The dependent variable $y_{i t}$ represents various measures of capital structure; $\gamma \psi \delta$, and $\phi$ are parameters to be estimated; and $G O V_{i, t-1}$ is the governance structure of firm $i$ in the year $t-1$. GOV is a $(6 \times 1)$ vector of ownership ratios, including banks (BKSH), other corporations (NBKSH), foreign institutional investors (FRGN), domestic private individuals (PRVT), inside investors (INSIDE), and the government and other stateowned agencies (GOVT) (see Section 2.2). SIZE represents firm size, ROA is the return on assets, TQR is Tobin's q ratio, RISK is earnings variability, TANG is the firm's collateral value, TAX is the corporate tax, LIQR is the quick ratio, and $\mathrm{HI}$ is the Herfindahl index. DUM comprises the 29 industries' dummy variables. The estimation consists of a cross-sectional individual effect $\alpha_{i}$ and the $\lambda_{t}$ time effect. SIZE, ROA, TQR, RISK, TANG, TAX, and LIQR are included to control for other relevant variables and heterogeneity in firms. The Herfindahl index enables us to control for ownership concentration.

Next, we estimate the following model to determine the impact of change in ultimate control:

$$
\begin{aligned}
& y_{i t}=\sum_{j=1}^{2} \gamma_{j}\left(y_{i, t-j}\right)+\left(G O V_{i, t-1}\right) \psi+\beta_{0} U C T_{\tau=0}+\beta_{1} U C T_{\tau=1}+\beta_{2} U C T_{\tau=2} \\
& +\delta_{1} S I Z E_{i t}+\delta_{2} R O A_{i t}+\delta_{3} T Q R_{i t}+\delta_{4} R I S K_{i t}+\delta_{5} T A N G_{i t}+\delta_{6} T A X_{i t}+\delta_{7} L I Q R_{i t} \\
& +\delta_{8} H I_{i t}+\sum_{p=1}^{29} \phi_{p} D U M_{i p}+\alpha_{i}+\lambda_{t}+\varepsilon_{i t}
\end{aligned}
$$

The $\gamma \psi \beta, \delta$ and $\phi$ terms are parameters to be estimated, and $U C T_{\tau}$ is the set of dummy variables that show the change in ultimate ownership. UCT is equal to 1 if the firm undergoes a change in control and 0 otherwise. Three different time periods are considered with $\tau$ for the year of change, $\tau$ for the first year after the change, and $\tau$ for the second year after the change in control.

In the third stage, we estimate a more detailed model comprising information about the entities to which ownership is transferred. As discussed previously, all transfers are categorized as transfers to financial institutions (FIT), to nonfinancial corporations (NFIT), to domestic private individuals and foreigners (PFIT), or to none of the above corporate entities (diverse transfers). The general model to be considered is written as follows: 


$$
\begin{aligned}
& y_{i t}=\sum_{j=1}^{2} \gamma_{j}\left(y_{i, t-j}\right)+\left(G O V_{i, t-1}\right) \psi+\beta_{1} F I T_{\tau=0}+\beta_{2} F I T_{\tau=1}+\beta_{3} F I T_{\tau=2} \\
& +\beta_{4} N F I T_{\tau=0}+\beta_{5} N F I T_{\tau=1}+\beta_{6} N F I T_{\tau=2}+\beta_{7} P F I T_{\tau=0}+\beta_{8} P F I T_{\tau=1}+\beta_{9} P F I T_{\tau=2} \\
& +\delta_{1} S I Z E_{i t}+\delta_{2} R O A_{i t}+\delta_{3} T Q R_{i t}+\delta_{4} R I S K_{i t}+\delta_{5} T A N G_{i t}+\delta_{6} T A X_{i t}+\delta_{7} L I Q R_{i t} \\
& +\delta_{8} H I_{i t}+\sum_{p=1}^{29} \phi_{p} D U M_{i p}+\alpha_{i}+\lambda_{t}+\varepsilon_{i t}
\end{aligned}
$$

Similar to the previous model in equation (5), we consider three different time periods with $\tau$ for the year of change in control, $\tau$ for the first year after the change in control, and $\tau$ for the second year after the change in control. Three categories of transfers are considered to assess the impact of transfers on restructuring activities and firms' financing behavior: FIT, NFIT, and PFIT are dummy variables indicating transfers to financial institutions, nonfinancial corporations, and private individuals, respectively. The reference category is transfers to diverse groups.

\subsection{Sample}

The dataset we use is based on firms' own financial accounts and contains corporate financial data on 1,362 firms that were publicly listed on the Tokyo Stock Exchange 1 and 2 during the period 1991 to 2009 (19 years). However, financial institutions (financial services comprising commercial banks, insurance companies, securities firms, and mutual funds) are not included in the sample because they have a special capital structure. Their capital structure is strongly influenced by investors' insurance schemes and debt-like liabilities that are not comparable to the debt issued by corporate (nonfinancial) firms. The data used in this analysis has been taken from the Nikkei Economic Electronic Databank System (NEEDS); the data on share prices used to calculate the market value-based measures is taken from the Toyo Keizai share prices database.

The initial sample consisted of financial data on more than 2,400 firms, but 1,099 firms were omitted because of missing data, either due to their recent entry in or delisting from the stock market. Our analysis is based, therefore, on the remaining 1,362 firms for the period 1991 to 2009, spread across 30 industrial categories. The distribution of sampled firms in various industries is based on the classification adopted by the Tokyo Stock Exchange. Tables 2 and 3 provide descriptive statistics for both the dependent variable(s) and explanatory variables. 
Table 2: Summary statistics of variables

\begin{tabular}{lrrrrrrr}
\hline Variable & Mean & \multicolumn{1}{c}{ Median } & \multicolumn{1}{c}{ Max. } & \multicolumn{1}{c}{ Min. } & \multicolumn{1}{c}{ SD } & Skewness & Kurtosis \\
\hline BLEV & 48.104 & 54.802 & 65.426 & 13.187 & 21.350 & 1.873 & 22.802 \\
MLEV & 46.693 & 46.732 & 68.625 & 8.080 & 21.493 & 0.002 & 12.191 \\
BKSH & 29.679 & 28.700 & 77.200 & 0.000 & 14.649 & 0.233 & 2.362 \\
NBKSH & 27.053 & 23.500 & 85.600 & 0.000 & 17.060 & 0.773 & 2.985 \\
FRGN & 7.644 & 3.900 & 35.800 & 0.000 & 9.499 & 2.130 & 9.069 \\
PRVT & 33.123 & 31.100 & 99.800 & 0.000 & 16.109 & 0.618 & 3.038 \\
INSIDE & 4.352 & 0.613 & 45.300 & 0.000 & 8.837 & 3.324 & 16.232 \\
GOVT & 0.126 & 0.092 & 65.782 & 0.000 & 1.921 & 23.982 & 14.650 \\
SIZE & 11.161 & 10.965 & 16.476 & 5.124 & 1.383 & 0.629 & 3.533 \\
ROA & 4.442 & 3.870 & 59.400 & -27.270 & 4.334 & 0.613 & 15.419 \\
TQR & 0.988 & 0.762 & 35.826 & 0.031 & 2.053 & 42.778 & 25.336 \\
RISK & 54.751 & 51.842 & 69.791 & 25.539 & 16.834 & 3.825 & 6.451 \\
TANG & 48.972 & 48.201 & 71.542 & 36.173 & 18.677 & 0.248 & 2.619 \\
TAX & 53.573 & 51.801 & 59.500 & -13.175 & 36.490 & 18.373 & 23.175 \\
LIQR & 125.316 & 99.080 & 145.126 & 36.378 & 38.488 & 11.140 & 42.825 \\
HI & 0.542 & 0.527 & 0.898 & 0.240 & 0.052 & 3.307 & 13.144 \\
UCT & 0.288 & - & 1 & 0 & 0.453 & 0.936 & 1.875 \\
FIT & 0.115 & - & 1 & 0 & 0.319 & 2.410 & 6.808 \\
NFIT & 0.075 & - & 1 & 0 & 0.263 & 3.239 & 11.488 \\
PFIT & 0.160 & - & 1 & 0 & 0.366 & 1.857 & 4.450 \\
\hline
\end{tabular}

Note: The selected sample consists of 1,362 firms for the period 1991 to 2009 (19 years). Thus, the total sample includes 25,878 observations.

Source: Authors' calculations.

The data for certain variables, such as the TQR and leverage, have outliers that could affect the regression results. We use the Winsorized transformation for possible outliers in the dataset, which limits extreme values to reduce the effect of possibly spurious outliers. All the outliers are set to 90 percent Winsorization, which sets data below the fifth percentile to the fifth percentile and data above the $95^{\text {th }}$ percentile to the $95^{\text {th }}$ percentile. 
Table 3: Summary of key ownership transfers

\begin{tabular}{llr}
\hline Variable & \multicolumn{1}{c}{ Description } & Firms \\
\hline UCT $(\mathrm{UCT}=1)$ & Firms experience change in control & 703 \\
UCT $(\mathrm{UCT}=0)$ & Firms that do not experience change in control & 659 \\
N & Total firms included in sample & 1,362 \\
FIT & Transfer of ultimate control to financial institutions & 232 \\
NFIT & Transfer of ultimate control to nonfinancial institutions & 159 \\
PFIT & Transfer of ultimate control to private individuals or & 389 \\
& foreign corporations \\
\hline
\end{tabular}

Source: Authors' calculations.

\section{Empirical Results}

Examining the effect of ultimate ownership reveals two general observations. On one hand, the signs and statistical significance of the regression coefficients for both measures of capital structure are stable. On the other, there are marked differences in the magnitude of impact of the explanatory variables on leverage.

\subsection{Ownership Structure and Capital Structure}

Table 4 shows the impact of ownership structure on leverage. The results support the idea that ownership structure strongly influences firms' leverage. Ownership concentration, represented by the Herfindahl index (HI), has a negative statistically significant effect on both measures of leverage (BLEV and MLEV). However, the magnitude of impact and statistical significance is higher for BLEV than for MLEV, suggesting that shareholders of a firm with more concentrated ownership may prefer less debt if debt brings about more monitoring (Leland \& Pyle, 1977; Diamond, 1984). It also shows that ownership concentration reduces the agency cost between managers and shareholders and facilitates equity.

In terms of ownership structure, $\mathrm{BKSH}$ is positively related to the debt-equity ratio. The estimated impact is highly statistically significant for both measures of leverage. The results suggest that firms with a higher percentage share owned by financial institutions are financed heavily by debt because of the affiliated firm's relationship with the main bank. This shows that the main bank system in Japan has enabled corporations to obtain funds efficiently and invest in relatively risky projects. This system propelled the postwar high growth of the Japanese economy. 
The ownership share of other affiliated firms, and foreign and domestic private individuals has an inverse relationship with market and book leverage. However, the estimated impact of private individuals' ownership on MLEV is statistically insignificant (but still negative). Although private and foreign individuals collectively hold smaller equity positions than stable investors, the size of their shareholdings and their influence appear to be on the rise. The ownership share of private and foreign individuals is consistently associated with a shift from bank debt to equity financing and the breakdown of banks' monopolistic power in the financial market.

Table 4: GMM results for impact of ownership structure

\begin{tabular}{lcccc}
\hline & \multicolumn{2}{c}{ BLEV } & \multicolumn{2}{c}{ MLEV } \\
\cline { 2 - 5 } Dependent variable & Coefficient & t-statistic & Coefficient & t-statistic \\
\hline LEV(-1) & $0.271^{* * *}$ & 23.500 & $0.282^{* * *}$ & 13.384 \\
LEV(-2) & $0.111^{* * *}$ & 7.455 & $0.016^{* *}$ & 1.938 \\
BKSH & $0.097^{* *}$ & 2.362 & $0.570^{* * *}$ & 8.914 \\
NBKSH & $-0.438^{*}$ & -1.736 & $-0.390^{* *}$ & -2.228 \\
FRGN & $-0.376^{* * *}$ & -4.794 & $-0.803^{* * *}$ & -4.470 \\
PRVT & $-0.777^{* * *}$ & 3.091 & -0.160 & -0.981 \\
INSIDE & $-0.212^{*}$ & -1.648 & 0.020 & 0.204 \\
GOVT & $-0.085^{*}$ & -1.782 & $-0.653^{* * *}$ & -4.098 \\
SIZE & $1.691^{* * *}$ & 7.937 & $1.929^{* * *}$ & 9.586 \\
ROA & $-0.684^{* * *}$ & -6.568 & $-0.021^{* *}$ & -2.264 \\
TQR & 0.563 & 1.458 & $-0.496^{* * *}$ & -5.366 \\
RISK & $-0.759^{* *}$ & -2.599 & $-0.150^{* * *}$ & -2.184 \\
TANG & $-0.439^{* * *}$ & -9.264 & $-0.218^{* * *}$ & -3.959 \\
TAX & $0.008^{* *}$ & 1.921 & $0.002^{* * *}$ & 2.093 \\
LIQR & $-0.019^{* * *}$ & -15.108 & $-0.018^{* * *}$ & -3.246 \\
HI & $-0.414^{* * *}$ & -7.693 & $-0.042^{* *}$ & -2.101 \\
Industry dummies & Yes & & Yes & \\
Period dummies & Yes & & Yes & \\
\hline Diagnostic tests & & & & 0.395 \\
J-stat. (p-value) & 0.623 & & 0.282 & \\
Lag 2 serial corr. (p-value) & 0.159 & & 0.217 & \\
DWH test stat. (p-value) & 0.189 & &
\end{tabular}

Notes: See equation (3) for a detailed definition of the estimated model. Both estimations include time control and industries' dummy variables (not reported).

The J-statistic ( $\mathrm{p}$-value) is the probability value of the Sargan test for over-identified restrictions. The lag 2 serial corr. ( $p$-value) is the probability value of the Arellano-Bond test indicating that the average autocorrelation in residuals of order 2 is 0 . The Durbin$\mathrm{Wu}-\mathrm{Hausman}(\mathrm{DWH})$ test statistic is employed to test for the exogeneity of the regressors. $*, * *$, and ${ }^{* * *}$ indicate statistical significance at a $0.10,0.05$, and 0.01 level of significance, respectively. $\mathrm{N}=23,154$.

Source: Authors' calculations. 
With an increase in the ownership share of market investors, the firm's management faces more pressure, which prevents it from building its own empire at the expense of shareholders. The inverse relationship between NBKSH and leverage is consistent with the standard theoretical assumption that cross-shareholding in the Japanese corporate market is generally not intended for short-term gains in income, but is for long-term or stable holding. In such a situation, firms have enough internal funds to finance their operations and are less dependent on bank debt.

Managerial ownership (INSIDE) is negatively associated with BLEV but only marginally significantly. The result is in accordance with Jensen and Meckling's (1976) "convergence of interest" hypothesis, which suggests that managerial ownership serves to align the interests of managers and outside shareholders. Thus, when managerial ownership increases, it limits the risk of wasting free cash flows and managers make fewer decisions that might have a negative effect on the firm's value-the part of costs that they will absorb as shareholders increases with their share of capital. The government ownership ratio has a negative significant impact on both measures of leverage, suggesting that, as state ownership increases, there is more pressure on the firm's management to limit the wasting of free cash flows.

The results indicate a positive relationship between firm size and BLEV and MLEV that is statistically significant at 1 percent. This supports the theory that size is an inverse proxy for the probability of bankruptcy. The positive relationship suggests that larger firms are better able to raise debt and are less vulnerable to bankruptcy than smaller firms. The relationship between leverage and profitability is negative and statistically significant at 1 percent in the case of BLEV and at 5 percent for MLEV. This finding favors the pecking order theory rather than the static tradeoff model. The inverse relationship can be explained by the significant differences in the information cost between external and internal finance. When there is significant information asymmetry between insiders and outsiders, firms must depend on internal sources before seeking external finance.

The results do not reveal clearly the relationship between leverage and growth opportunities. When measured as MLEV, we find a negative relationship between leverage and growth opportunities that is statistically significant at 1 percent. However, when BLEV is considered the dependent variable, we find a positive but statistically insignificant relationship. The negative relationship is consistent with the signaling theory; this suggests 
that, when the firm pursues a growth-oriented strategy and future prospects are not favorable, it will avoid debt financing and will sell stock to reduce its future liabilities and bring in new shareholders to share its higher expected future liabilities.

The relationship between risk and leverage is significant at 5 percent and is negative in both cases. ${ }^{6}$ The negative sign implies that volatility is a proxy for the risk of a firm. The model indicates a negative relationship between leverage and tangibility that is statistically significant at 1 percent for both BLEV and MLEV. This is due partly to the institutional environment, which, in the case of firm bankruptcy, induces obstacles and lowers asset value. Such an effect might explain the existence of no relationship, but it is not very likely to cause a negative relationship. The theory should provide some additional explanation.

With regard to the debt tax shield variable, we find a positive relationship with leverage (consistent with corporate finance theory) that is statistically significant at 5 percent. The results suggest that the tax advantages of debt are attractive to firms in Japan-a company can reduce its after-tax cost of capital by increasing debt relative to equity, and thereby directly increasing its intrinsic value. The estimated relationship between liquidity and leverage is negative and significant at 1 percent in both cases, which is consistent with the pecking order theory. Liquid firms prefer internal equity and use less debt.

Many empirical studies have controlled for industry classification in their models (see Huang \& Song, 2002; Frank \& Goyal, 2003; Kim, Heshmati, \& Aoun, 2006), but they do not provide explicit results. We have included dummy variables for 29 industries in our model and classified these industries into 30 economic groups based on the classification adopted by the Tokyo Stock Exchange. It is interesting to note that most of the dummies are statistically significant and their sign does not vary much across different measures of leverage.

The results for size, profitability, risk, tax, and liquidity are similar to those given in most other empirical studies, but ambiguous in the case of growth opportunities and the tangibility ratio. In the case of growth opportunities, the results are based on the definition of leverage.

\footnotetext{
${ }^{6}$ An alternative measure of firm risk, the capital asset pricing model (CAPM) beta, is also used in the regression analysis. The estimated coefficient is negative and statistically significant at 5 percent for both measures of leverage. The risk of each firm is calculated using stock market monthly data on returns from 1987 to 2009 . Using the past five years' monthly returns (60 observations), we estimate the CAPM developed by Sharpe (1964) and Lintner (1965) to compute the CAPM beta.
} 


\subsection{Changes in Ultimate Ownership and Capital Structure}

Table 5 helps to assess the impact of change in ultimate control, based on the results for equation (4). The estimated impacts of governance structure, ownership concentration, and other control variables are similar to the results in Table 4 in terms of statistical significance and sign, but there are minor variations in magnitude.

Table 5: GMM results for impact of change in ultimate ownership

\begin{tabular}{|c|c|c|c|c|}
\hline \multirow[b]{2}{*}{ Dependent variable } & \multicolumn{2}{|c|}{ BLEV } & \multicolumn{2}{|c|}{ MLEV } \\
\hline & Coefficient & t-statistic & Coefficient & t-statistic \\
\hline$\overline{\mathrm{LEV}(-1)}$ & $0.271^{* * *}$ & 24.85 & $0.281^{* * *}$ & 13.431 \\
\hline $\operatorname{LEV}(-2)$ & $0.110^{* * *}$ & 7.752 & $0.015^{* * *}$ & 1.873 \\
\hline $\mathrm{BKSH}$ & $0.104^{* *}$ & 2.490 & $0.579^{* * *}$ & 8.988 \\
\hline NBKSH & $-0.419^{*}$ & -1.651 & $-0.412^{* * *}$ & -2.355 \\
\hline FRGN & $-0.368^{* * *}$ & -4.515 & $-0.816^{* * *}$ & -4.563 \\
\hline PRVT & $-0.767^{* * *}$ & 3.135 & -0.180 & -1.106 \\
\hline INSIDE & $-0.219^{*}$ & -1.702 & 0.031 & 0.320 \\
\hline GOVT & $-0.064^{*}$ & -1.782 & $-0.639 * * *$ & -4.101 \\
\hline SIZE & $1.688^{* * *}$ & 8.009 & $1.931^{* * *}$ & 9.190 \\
\hline ROA & $-0.679^{* * *}$ & -6.336 & $-0.019^{* *}$ & -2.198 \\
\hline TQR & 0.564 & 1.408 & $-0.489^{* * *}$ & -5.373 \\
\hline RISK & $-0.739^{* *}$ & -2.387 & $-0.161^{* * *}$ & -3.221 \\
\hline TANG & $-0.454^{* * *}$ & -9.287 & $-0.216^{* * *}$ & -3.933 \\
\hline TAX & $0.009^{* *}$ & 1.952 & $0.003^{*}$ & 1.713 \\
\hline LIQR & $-0.019^{* * *}$ & -15.066 & $-0.018^{* * *}$ & -3.242 \\
\hline $\mathrm{HI}$ & $-0.487^{* * *}$ & -5.030 & $-0.051^{* *}$ & -2.230 \\
\hline$U C T_{\tau=0}$ & $-1.559^{* * *}$ & -3.598 & $-0.602^{* *}$ & -1.907 \\
\hline$U C T_{\tau=1}^{i-0}$ & $-1.192^{* *}$ & -2.261 & $-1.348^{* *}$ & -2.197 \\
\hline$U C T_{\tau=2}^{-1}$ & 0.434 & 0.415 & $-0.796^{*}$ & -1.708 \\
\hline Industry dummies & Yes & & Yes & \\
\hline Period dummies & Yes & & Yes & \\
\hline \multicolumn{5}{|l|}{ Diagnostic tests } \\
\hline J-stat. (p-value) & 0.474 & & 0.188 & \\
\hline Lag 2 serial corr. (p-value) & 0.241 & & 0.169 & \\
\hline DWH test stat. (p-value) & 0.389 & & 0.416 & \\
\hline
\end{tabular}

Note: See equation (4) for a detailed definition of the estimated model. Both estimations include time control and industries' dummy variables (not reported).

The J-statistic ( $p$-value) is the probability value of the Sargan test for over-identified restrictions. The lag 2 serial corr. (p-value) is the probability value of the Arellano-Bond test indicating that the average autocorrelation in residuals of order 2 is 0 . The Durbin$\mathrm{Wu}-$ Hausman $(\mathrm{DWH})$ test statistic is employed to test for the exogeneity of the regressors. $*, * *$, and ${ }^{* * *}$ indicate statistical significance at a $0.10,0.05$, and 0.01 level of significance, respectively. $\mathrm{N}=23,154$.

Source: Authors' calculations. 
The results for the change in ownership confirm our earlier predictions. The estimated coefficient for the year of change and the first year after the change in control is negative and statistically significant. However, in the case of BLEV, the coefficient is positive and statistically insignificant even at 10 percent for the second year after the change in ultimate ownership. With regard to MLEV, leverage falls at all three points in time but the fall is higher in the first year after the change than in the other two periods. Overall, the results in Table 5 suggest that leverage measured either in terms of book value or market value falls in the year of change in control and in the subsequent period. Thus, change in ownership is followed by an alteration in the firm's capital structure.

\subsection{Transfer of Control to Various Corporate Entities and Capital Structure}

We now compare transfers to various corporate entities by estimating equation (5), employing the GMM two-step estimation method. This model takes into account information regarding the transaction parties involved, and includes all the control and governance structure variables, along with the ownership transfer dummies FIT, NFIT, and PFIT. To conserve space, Table 6 reports only the results for the impact of ownership transfer observed in three distinct periods. The estimated impacts of governance structure, ownership concentration, and other control variables are similar to the results in Table 4 in terms of statistical significance, sign, and magnitude. There is, however, a marked difference in the impact of change in ownership on capital structure measures among FIT, NFIT, and PFIT.

Overall, the results in Table 6 support the results obtained in the first stage by estimating equation (3). The impact of change in ultimate ownership is negative for transfers to private individuals and nonfinancial institutions and positive for transfers to financial institutions. Leverage falls in the year of change of control, but it increases in the subsequent two periods. The effect is much stronger in the case of MLEV. This is consistent with the premise of the main bank relationship with the affiliated firm.

We also find an inverse relationship between NFIT and PFIT and capital structure. For nonfinancial institutions, BLEV falls in the year of change and in the first year after the transfer of control; in the case of MLEV, capital structure is unaffected in the year of transfer but leverage falls in the subsequent two periods. Similarly, for transfers to private

individuals, both BLEV and MLEV remain statistically the same as the pre- 
transfer level in the year of change, and there is a significant decrease in the debt ratio in the first and second years after the transfer.

Table 6: GMM results for impact of change in ownership transfer to various corporate entities

\begin{tabular}{lcccc}
\hline & \multicolumn{2}{c}{ BLEV } & \multicolumn{2}{c}{ MLEV } \\
\cline { 2 - 5 } Dependent variable & Coefficient & t-statistic & Coefficient & t-statistic \\
\hline$F I T_{\tau=0}$ & $-1.215^{*}$ & -1.813 & $-0.947^{*}$ & -1.661 \\
$F I T_{\tau=1}$ & $4.725^{* * *}$ & 5.199 & $5.452^{* * *}$ & 7.911 \\
$F I T_{\tau=2}$ & $3.103^{*}$ & 1.796 & $3.506^{* * *}$ & -7.979 \\
$N F I T_{\tau=0}$ & $-0.733^{* *}$ & -2.046 & 0.259 & 0.765 \\
$N F I T_{\tau=1}$ & $-0.055^{* *}$ & -0.123 & $-0.511^{* *}$ & -2.318 \\
$N F I T_{\tau=2}$ & 0.495 & 0.448 & $-2.111^{* * *}$ & -2.774 \\
$P F I T_{\tau=0}$ & 0.379 & 1.378 & 0.080 & 0.285 \\
$P F I T_{\tau=1}$ & $-0.244^{* * *}$ & -2.781 & $-0.599^{* *}$ & 2.289 \\
$P F I T_{\tau=2}$ & $-0.197^{* *}$ & -2.242 & $-0.614^{* * *}$ & -2.972 \\
Industry dummies & Yes & & Yes & \\
Period dummies & Yes & & Yes & \\
\hline Diagnostic tests & & & & 0.671 \\
J-stat. (p-value) & 0.297 & & 0.292 & \\
Lag 2 serial corr. (p-value) & 0.112 & & & \\
DWH test stat. (p-value) & 0.236 & & & \\
\hline
\end{tabular}

Note: See equation (5) for a detailed definition of the estimated model. Both estimations include time control and industries' dummy variables (not reported).

The J-stat. (p-value) is the probability value of the Sargan test for over-identified restrictions. The lag 2 serial corr. (p-value) is the probability value of the Arellano-Bond test indicating that the average autocorrelation in residuals of order 2 is 0 . The Durbin$\mathrm{Wu}$-Hausman (DWH) test statistic is employed to test for the exogeneity of the regressors. ${ }^{*}, *$, and ${ }^{* * *}$ indicate statistical significance at a $0.10,0.05$, and 0.01 level of significance, respectively. $\mathrm{N}=23,154$.

Source: Authors' calculations.

Tables 4, 5, and 6 also report the p-value of specification tests applied to the dynamic panel data model. In all three cases, the Sargan test (J-statistic) results do not reject the null hypothesis that the over-identified restrictions are valid. Similarly, in most cases, the null hypothesis of no second-order autocorrelation is not rejected. The Durbin-Wu-Hausman (DWH) test results for the exogeneity of regressors imply that the underlying models do not suffer from an endogeneity problem (for a detailed discussion, see Cameron \& Trivedi, 2009). The DWH test is carried out to check if GOV causes an endogeneity bias. In sum, the specification tests support the overall validity of these models. 


\section{Robustness of Results}

An additional potential concern associated with the Arellano and Bond (1991) GMM estimator is the weak instruments problem of instrumental variable estimators (see Wooldridge, 2002, for an illustration). Large finite sample biases can occur when the instrumental variables are weak, and this difficulty carries over into the GMM estimation of dynamic panel data models. ${ }^{7}$ When the time series are persistent and the number of time-series observations is small, the first-differenced GMM estimator behaves poorly because, under these conditions, the lagged levels of the variables are only weak instruments for subsequent first-differences (see Bond \& Windmeijer, 2001). Since the previously applied Sargan test does not reject the null hypothesis that the over-identification restrictions are valid, this problem is unlikely to affect our results.

The takeover decision also depends on the firm's leverage (Novaes \& Zingales, 1995), and therefore we cannot completely rule out the possibility of endogeneity in the models. However, there is a broad consensus in the literature on panel data models that GMM accounts for endogeneity in such models.

Nonetheless, to explicitly address these two issues, we present a fixed-effects formulation of equations (3), (4), and (5) along with the following equation, which describes the impact of leverage on ownership structure. These are then estimated using the fixed-effects two-stage leastsquares method (FE-2SLS).

$$
G O V_{i t}=\beta_{0}+\beta_{1} L E V_{i, t-1}+\beta_{2} R O A_{i t-1}+\beta_{3} T Q R_{i t-1}+\beta_{4} S I Z E_{i t}+\alpha_{i}+\lambda_{t}+\varepsilon_{i t}
$$

LEV is the leverage of the firm, measured as BLEV or MLEV. GOV is the ownership structure and includes BKSH, NBKSH, FRGN, PRVT, INSIDE, and GOVT. SIZE and time dummies are included to account for the effect of economies of scale and time, respectively. ROA and TQR are included because of the consensus that the firm's ownership structure depends on the performance and investment opportunities available to it. ${ }^{8}$

Although a fixed-effects model that includes a lagged dependent variable as the regressor can lead to biased estimates, this approach still

\footnotetext{
${ }^{7}$ On weak instrument biases, see Nelson and Startz (1988, 1990) and Staiger and Stock (1997), among others. For a discussion in the context of panel data, see Blundell and Bond (1998).

${ }^{8}$ The industry dummy variables are dropped from the fixed-effects model because it is constant over time for each firm.
} 
serves as a benchmark. The estimators are consistent as $\mathrm{N}$ or $\mathrm{T}$ approach infinity and can be used to verify the robustness of the GMM results.

In the first stage, we apply the Hausman (1978) specification test to evaluate the relationship between the individual-specific effect $\alpha_{i}$ and other explanatory variables. The test is used whether a fixed effects or random effects formulation is more appropriate for estimating these parameters. The chi-squared values computed are tabulated in Table 7.

The test results imply that the individual-specific effects are correlated with the right-hand side variables. The random-effects estimates appear to be significantly biased with a high probability. Therefore, the fixed-effects model seems more appropriate for estimating the model specified in (3), (4), (5), and (6).

\section{Table 7: Hausman test results}

\begin{tabular}{lcccccc}
\hline & Chi-sq. stat. & df & Prob. & Chi-sq. stat. & df & Prob. \\
\hline Panel 1: Model of impact of ownership structure on leverage \\
\hline \multicolumn{3}{c}{ BLEV } \\
\hline Dependent variable & 340.647 & 35 & 0.000 & 181.483 & 35 & 0.000 \\
\hline Model 1 (equation 3) & 364.105 & 38 & 0.000 & 189.004 & 38 & 0.000 \\
Model 2 (equation 4) & 339.512 & 44 & 0.000 & 164.270 & 44 & 0.000 \\
\hline Model 3 (equation 5) & \multicolumn{7}{c}{ BLEV } \\
\hline Panel 2: Model of impact of leverage on ownership structure (equation 6) \\
\hline LEV is represented by & 256.851 & 20 & 0.000 & 291.537 & 20 & 0.000 \\
\hline BKSH (equation 6) & 150.391 & 20 & 0.000 & 821.721 & 20 & 0.000 \\
NBKSH (equation 6) & 328.621 & 20 & 0.000 & 338.592 & 20 & 0.000 \\
FRGN (equation 6) & 216.210 & 20 & 0.000 & 210.083 & 20 & 0.000 \\
PRVT (equation 6) & 210.421 & 20 & 0.000 & 345.173 & 20 & 0.000 \\
INSIDE (equation 6) & 301.003 & 20 & 0.000 & 109.007 & 20 & 0.000 \\
GOVT (equation 6) & \multicolumn{7}{c}{ MLEV } \\
\hline
\end{tabular}

Note: $\mathrm{df}=$ degrees of freedom (number of restrictions).

Source: Authors' calculations.

In the second stage, we estimate the fixed-effects specification of equation (6) and use the fitted GOV (denoted as $\overline{G O V}$ ) as an instrument for GOV in the system of equations specified in (3), (4), and (5). Subsequently, the fixed-effects models are estimated using equations (3), (4), and (5) for both measures of leverage. The results for the impact of ownership structure and other control variables are presented in Table 8. 
Table 8: FE-2SLS results for impact of ownership structure

\begin{tabular}{lcccc}
\hline & \multicolumn{2}{c}{ BLEV } & \multicolumn{2}{c}{ MLEV } \\
\cline { 2 - 5 } Dependent variable & Coefficient & t-statistic & Coefficient & t-statistic \\
\hline Intercept & $18.018^{* * *}$ & 3.599 & $12.340^{* * *}$ & 3.136 \\
LEV(-1) & $0.118^{* * *}$ & 4.932 & $0.340^{* * *}$ & 3.341 \\
LEV(-2) & $0.744^{* * *}$ & 5.746 & $0.493^{* * *}$ & 79.720 \\
BKSH & $0.083^{* *}$ & 2.127 & $0.578^{* * *}$ & 3.578 \\
NBKSH & $-0.404^{* * *}$ & -2.499 & $-0.374^{* * *}$ & -6.051 \\
FRGN & $-0.311^{* *}$ & -1.940 & $-0.808^{* *}$ & -1.932 \\
PRVT & $-0.792^{* * *}$ & -5.158 & -0.151 & -1.059 \\
INSIDE & $-0.225^{* * *}$ & 3.048 & 0.019 & 0.196 \\
GOVT & $-0.066^{* * *}$ & -6.750 & $-0.654^{* * *}$ & -8.788 \\
SIZE & $1.565^{* *}$ & 3.958 & $1.383^{* *}$ & 2.307 \\
ROA & $-0.643^{* * *}$ & -3.696 & $-0.031^{* * *}$ & -2.912 \\
TQR & $0.499^{* * *}$ & 1.462 & $-0.514^{* * *}$ & -5.491 \\
RISK & $-0.704^{* *}$ & -2.259 & $-0.184^{* * *}$ & -4.535 \\
TANG & $-0.475^{* * *}$ & -4.992 & $-0.237^{* * *}$ & -6.445 \\
TAX & $0.009^{* * *}$ & 35.028 & $0.002^{* * *}$ & 5.934 \\
LIQR & $-0.017^{*}$ & -1.685 & $-0.015^{* * *}$ & -2.705 \\
HI & $-0.409^{* * *}$ & -3.011 & $-0.047^{* * *}$ & -3.290 \\
Period dummies & Yes & & Yes & \\
\hline Diagnostic tests & & & & \\
Adjusted R-sq. & 0.686 & & 0.713 & \\
F-stat. (p-value) & 0.000 & & 0.000 & \\
LM serial corr. test (p-value) & 0.281 & & & \\
\hline & & & & \\
Note See & & & & \\
\hline
\end{tabular}

Note: See equations (3) and (6) for a detailed definition of the estimated model. Both estimations include time control (not reported).

The LM serial corr. test (p-value) is the probability value of the Breusch-Godfrey test for second-order serial correlation. The null hypothesis is that the second-order residuals' correlation is 0 .

$*, * *$, and ${ }^{* * *}$ indicate statistical significance at the $0.10,0.05$, and 0.01 level of significance, respectively. $\mathrm{N}=23,154$.

Source: Authors' calculations.

Examining the effect of ultimate ownership reveals that the signs and statistical significance of the regression coefficients are similar to those given in Table 4. Table 9 gives the results for the impact of change in ultimate ownership regardless of the identity of the transaction parties involved, based on an FE-2SLS specification. 
Table 9: FE-2SLS results for impact of change in ultimate ownership

\begin{tabular}{|c|c|c|c|c|}
\hline \multirow[b]{2}{*}{ Dependent variable } & \multicolumn{2}{|c|}{ BLEV } & \multicolumn{2}{|c|}{ MLEV } \\
\hline & Coefficient & t-statistic & Coefficient & t-statistic \\
\hline $\mathrm{C}$ & $18.207^{* * *}$ & 6.687 & $12.538^{* * *}$ & 3.376 \\
\hline $\operatorname{LEV}(-1)$ & $0.264^{* * *}$ & 5.611 & $0.294^{* * *}$ & 7.665 \\
\hline $\operatorname{LEV}(-2)$ & $0.013^{* *}$ & 2.037 & $0.018^{* * *}$ & 3.537 \\
\hline BKSH & $0.106^{* *}$ & 2.059 & $0.575^{* * *}$ & 6.027 \\
\hline NBKSH & $-0.406^{* * *}$ & 4.160 & $-0.408^{* *}$ & -2.073 \\
\hline FRGN & $-0.389^{* * *}$ & -9.752 & $-0.803^{* * *}$ & -7.157 \\
\hline PRVT & $-0.728^{* * *}$ & -3.373 & -0.220 & -0.852 \\
\hline INSIDE & $-0.213^{* * *}$ & -6.336 & 0.044 & 0.751 \\
\hline GOVT & $-0.054^{* *}$ & -1.937 & $-0.684^{* *}$ & -2.312 \\
\hline SIZE & $1.649^{* * *}$ & 4.598 & $1.978^{* * *}$ & 5.961 \\
\hline ROA & $-0.696^{* * *}$ & -6.029 & $-0.021^{* * *}$ & -5.460 \\
\hline TQR & 0.516 & 0.365 & $-0.487^{* * *}$ & -4.470 \\
\hline RISK & $-0.748^{* * *}$ & -4.470 & $-0.174^{* * *}$ & -6.445 \\
\hline TANG & $-0.417^{* * *}$ & -4.118 & $-0.258^{* * *}$ & -4.802 \\
\hline TAX & $0.008^{*}$ & 1.643 & $0.003^{* * *}$ & 2.716 \\
\hline LIQR & $-0.018^{* * *}$ & -3.948 & $-0.017^{* * *}$ & -5.299 \\
\hline HI & $-0.443^{* * *}$ & -3.753 & $-0.057^{* * *}$ & -3.728 \\
\hline$U C T_{\tau=0}$ & $-1.496^{*}$ & -1.725 & $-1.297^{*}$ & 1.681 \\
\hline$U C T_{\tau=1}$ & $-1.197^{* * *}$ & -3.567 & $-1.385^{* * *}$ & -4.646 \\
\hline$U C T_{\tau=2}$ & 0.402 & 0.012 & $-0.814^{* *}$ & -2.091 \\
\hline Period dummies & Yes & & Yes & \\
\hline \multicolumn{5}{|l|}{ Diagnostic tests } \\
\hline Adjusted R-sq. & 0.696 & & 0.733 & \\
\hline F-stat. (p-value) & 0.000 & & 0.000 & \\
\hline LM serial corr. test ( $\mathrm{p}$-value) & 0.238 & & 0.436 & \\
\hline
\end{tabular}

Note: See equations (4) and (6) for a detailed definition of the estimated model. Both estimations include time control (not reported).

The LM serial corr. test ( $\mathrm{p}$-value) is the probability value of the Breusch-Godfrey test for second-order serial correlation. The null hypothesis is that the second-order residuals' correlation is 0 .

$*, * *$ and ${ }^{* * *}$ indicate statistical significance at the $0.10,0.05$, and 0.01 level of significance, respectively. $\mathrm{N}=23,154$.

Source: Authors' calculations.

For further insight into the impact of ownership change, in the third stage we estimate a more detailed model that includes information on the 
entities to which ownership is transferred. The results are presented in Table 10. The estimated equation includes all the control and governance structure variables and period dummy variables (not reported) along with the ownership transfer dummies FIT, NFIT, and PFIT. The table reports only the results for the impact of ownership transfer observed in three distinct time periods.

Table 10: FE-2SLS results for impact of change in ownership transfer to various corporate entities

\begin{tabular}{lcccc}
\hline & \multicolumn{2}{c}{ BLEV } & \multicolumn{2}{c}{ MLEV } \\
\cline { 2 - 5 } Dependent variable & Coefficient & t-statistic & Coefficient & t-statistic \\
\hline$F I T_{\tau=0}$ & $-1.148^{* *}$ & -2.232 & $-0.097^{*}$ & 1.629 \\
$F I T_{\tau=1}$ & $4.616^{* *}$ & 2.797 & $5.321^{* * *}$ & 3.556 \\
$F I T_{\tau=2}$ & $3.066^{* *}$ & 2.324 & $3.365^{* *}$ & 3.137 \\
$N F I T_{\tau=0}$ & $-0.699^{* * *}$ & -4.505 & 0.252 & 0.194 \\
$N F I T_{\tau=1}$ & $-0.059^{* *}$ & -1.993 & $-0.512^{* * *}$ & -4.036 \\
$N F I T_{\tau=2}$ & 0.462 & 0.752 & $-2.103^{* *}$ & -1.952 \\
$P F I T_{\tau=0}$ & -0.316 & -0.056 & 0.064 & 1.232 \\
$P F I T_{\tau=1}$ & $-0.217^{* *}$ & -1.937 & $-0.612^{* * *}$ & -3.043 \\
$P F I T_{\tau=2}$ & $-0.184^{* *}$ & -1.981 & $-0.626^{* *}$ & -2.094 \\
Period dummies & Yes & & Yes & \\
\hline Diagnostic tests & & & & 0.753 \\
Adjusted R-sq. & 0.756 & & 0.000 & \\
F-stat. (p-value) & 0.000 & & 0.648 & \\
LM serial corr. test (p-value) & 0.146 & & & \\
\hline
\end{tabular}

Note: See equations (5) and (6) for a detailed definition of the estimated model. Both estimations include time control (not reported).

The LM serial corr. test (p-value) is the probability value of the Breusch-Godfrey test for second-order serial correlation. The null hypothesis is that the second-order residuals' correlation is 0 .

$*, * *$, and $* * *$ indicate statistical significance at the $0.10,0.05$, and 0.01 level of significance, respectively. $\mathrm{N}=23,154$.

Source: Authors' calculations.

In summary, the estimates yielded by the two-stage method are unchanged in terms of statistical significance, but there are minor deviations in the magnitude of impact. However, these are negligible and may have arisen because the industry-specific dummy variables were dropped. Therefore, the GMM estimation results can be used as benchmarks to evaluate the impact of ownership change on firm financing behavior. The fixed-effects specification results show that the GMM estimates are consistent and robust. 


\section{Concluding Remarks}

Our study has shown that using GMM rather than other panel estimation methods has clear advantages in a model characterized by heteroskedasticity and endogeneity. Although the GMM estimator is more efficient than other estimators, it would not be asymptotically worse in the absence of heteroskedasticity. Nevertheless, the use of GMM comes at a price. The problem, as Hayashi (2001) points out, is that the optimal weighting matrix at the core of efficient GMM is a function of fourth moments, obtaining reasonable estimates of which would require very large samples. The consequence is that the efficient GMM estimator may have poor small-sample properties. In particular, Wald tests tend to overreject the null hypothesis.

Since the results presented above are not completely free from the problems that generally arise in panel data estimation (even if using a more standard econometric model, estimation technique, and robustness tests), we cannot argue that the method avoids all problems. Thus, further tests are necessary to estimate more accurate results, but these results have several important implications.

First, firms with more concentrated ownership may prefer less debt as ownership concentration reduces the extent of agency costs between managers and shareholders and facilitates equity. Firms that lack the disciplinary role of ultimate owners are more inclined toward debt financing.

Second, firms with a higher percentage share owned by financial institutions are financed heavily by debt because of the affiliated firm's relationship with the main bank. The main bank system enables corporations to obtain funding efficiently and invest in relatively risky projects. The positive relationship between transfers to financial institutions and leverage suggests that unwinding the cross-shareholding between banks and corporations yields efficiency gains. While banks still hold significant equity positions and have large influence over corporations, both their shareholding and influence are declining with the changing relationship between financial institutions and their client firms in Japan.

Third, although private and foreign individuals still collectively hold smaller equity positions than stable investors, the size of their shareholdings and their influence appear to be on the rise. The ownership share of private and foreign individuals is consistently associated with a 
shift from bank debt to equity financing and the breakdown of banks' monopolistic power in the financial market. Ownership transfer to other affiliated corporations, and to private and foreign individuals is invariably associated with high efficiency in expenditure and raising funds through equity financing. Mutual transfers among nonfinancial institutions do not have a significant positive impact on leverage.

Fourth, managerial ownership serves to align the interests of managers and outside shareholders. Thus, when managerial ownership increases, the risk of wasting free cash flows is limited and managers make fewer decisions that might have a negative effect on the firm's value. Government ownership is also associated with more pressure on the management to limit the wasting of free cash flows.

Finally, the relative power of stable and market investors to influence corporate behavior is undergoing an important change. The results provide clear evidence that changes in control are followed by improvements in the efficiency of fund raising. Changes in ultimate ownership also lead to major asset and capital restructuring in subsequent years. 


\section{References}

Arellano, M., \& Bond, S. (1991). Some tests of specification for panel data: Monte Carlo evidence and an application to employment equations. Review of Economic Studies, 58(2), 277-297.

Barclay, M. J., \& Clifford, W. S., Jr. (1995). The maturity structure of corporate debt. Journal of Finance, 50, 609-631.

Bauer, P. (2004). Determinants of capital structure: Evidence from Czech Republic. Czech Journal of Economics and Finance, 54, 2-21.

Blundell, R., \& Bond, S. (1998). Initial conditions and movements restrictions in dynamic panel data models. Journal of Econometrics, $87,115-143$.

Bond, S., \& Windmeijer, F. (2001). Projection estimators for autoregressive panel data models (Working Paper No. CWP 06/01). London, UK: Institute of Fiscal Studies.

Booth, L., Aivazian, V., Demirguc-Kunt, A., \& Maksimovic, V. (2001). Capital structure in developing countries. Journal of Finance, 56, 87-113.

Cameron, A. C., \& Trivedi, P. K. (2009). Microeconometrics using Stata. College Station, TX: Stata Press.

Charkham, J. (1994). Keeping good company: A study of corporate governance in five countries. Oxford, UK: Oxford University Press.

Diamond, D. (1984). Financial intermediation and delegated monitoring. Review of Economic Studies, 51, 393-414.

Fama, E., \& French, K. R. (2005). Financing decisions: Who issues stock? Journal of Financial Economics, 76, 549-582.

Frank, M., \& Goyal, V. (2003). Testing the pecking order theory of capital structure. Journal of Financial Economics, 67, 217-248.

Fuji Research Institute. (1993). Mein banku shisutemu oyobi kabushiki mochiai ni tsuite no chousa houkoku [Research report on the main bank system and cross shareholding]. Tokyo, Japan: Ministry of International Trade and Industry. 
Gerlach, M. L. (1992). Alliance capitalism: The social organization of Japanese business. Berkeley, CA: University of California Press.

Hausman, J. A. (1978). Specification tests in econometrics. Econometrica, $46,1251-1271$.

Hayashi, F. (2001). Identifying a liquidity effect in the Japanese interbank market. International Economic Review, 42(2), 287-315.

Himmelberg, C. P., Hubbard, R. G., \& Palia, D. (1999). Understanding the determinants of managerial ownership and the link between ownership and performance. Journal of Financial Economics, 53, 353-384.

Huang, S. G., \& Song, F. M. (2002). The determinants of capital structure: Evidence from China (Working Paper No. 1042). Hong Kong: Hong Kong Institute of Economics and Business Strategy.

Inoue, H. (1999). The accelerating dissolution of stock cross-holding. Tokyo, Japan: NLI Research Institute.

Jensen, M., \& Meckling, W. (1976). Theory of the firm: Managerial behaviors, agency costs, and ownership structure. Journal of Financial Economics, 3, 305-360.

Kim, H., Heshmati, A., \& Aoun, D. (2006). Dynamics of capital structure: The case of Korean listed manufacturing companies. Asian Economic Journal, 20(3), 275-302.

Leland, H., \& Pyle, D. (1977). Information asymmetries, financial structure, and financial intermediation. Journal of Finance, 32, 371387.

Lincoln, J. R., Gerlach, M., \& Ahmadjian, C. (1996). Keiretsu networks and corporate performance in Japan. American Sociological Review, 61, $67-88$.

Lintner, J. (1965). The valuation of risk assets and the selection of risky investments in stock portfolios and capital budgets. Review of Economics and Statistics, 47, 13-37.

MacKay, P., \& Phillips, G. (2005). How does industry affect firm financial structure? Review of Financial Studies, 18(4), 1432-1466. 
Miller, M. (1977). Debt and taxes. Journal of Finance, 32, 261-275.

Myers, S. (1977). Determinants of corporate borrowing. Journal of Financial Economics, 5, 147-176.

Nelson, C., \& Startz, R. (1988). The distribution of the instrumental variables estimator and its t-ratio when the instrument is a poor one (Discussion Papers in Economics No. 88-07). Seattle, WA: University of Washington, Department of Economics.

Nelson, C., \& Startz, R. (1990). More on the exact small sample distribution of the instrumental variable estimator: A reply to Maddala and Jeong (Discussion Papers in Economics No. 90-29). Seattle, WA: University of Washington, Department of Economics.

Novaes, W., \& Zingales, L. (1995). Capital structure choice when managers are in control: Entrenchment versus efficiency (Working Paper No. 5384). Cambridge, MA: National Bureau of Economic Research.

Prowse, S. D. (1990). Institutional investment patterns and corporate financial behavior in the United States and Japan. Journal of Financial Economics, 27(1), 43-66.

Sharpe, W. F. (1964). Capital asset prices: a theory of market equilibrium under conditions of risk. Journal of Finance, 19(3), 425-442.

Staiger, D., \& Stock, J. H. (1997). Instrumental variables regression with weak instruments. Econometrica, 65(3), 557-586.

Weinstein, D. E., \& Yafeh, Y. (1998). On the costs of a bank-centered financial system: Evidence from the changing main bank relations in Japan. Journal of Finance, 53(2), 635-672.

Welch, I. (2004). Capital structure and stock returns. Journal of Political Economy, 112(1), 106-131.

Wooldridge, J. M. (2002), Econometric analysis of cross section and panel data. Cambridge, MA: MIT Press.

Yasui, T. (1999, March). Corporate governance in Japan. Paper presented at the OECD Conference on Corporate Governance in Asia: A Comparative Perspective, Seoul, Korea. 
Annex

\section{The Reforms Process in Japan}

Between the 1950s and 1980s, rapid economic growth contributed to high returns on financial assets - especially on stocks-in Japan. The market bubble burst at the end of the 1980s, however, changed investment behavior along with the structure of the market, and led to the "lost" decade of the 1990s. During this period, all asset classes (except bonds) performed dismally as the interest rate fell to its minimum level and returns on stocks remained negative. The overall economy and the financial market in particular stumbled because of the slow pace of structural change and the substantial impact of massive bad loans.

Japan's "lost" decade is considered similar to the Great Depression that followed the 1929 stock market crash in the US. At the end of 1929, the Dow Jones industrial average stood at 164.58 and only after 16 years did the index reach 192.91. The performance of Japan's stock market after the market bubble burst mirrors the performance of the US market in the wake of the 1929 crash.

In order to restore economic growth and move toward a more efficient and competitive market-based system, the Japanese government introduced ambitious and wide-ranging reforms in the 1990s to remove inefficiencies and market distortions. These restructuring reforms were directed at strengthening the capital market. Measures included, among others, deregulating the banking sector, refining the interbank funding markets, opening up domestic financial markets to foreign investors, allowing domestic investors to participate in financial markets overseas, corporate governance, improving asset quality, consumer financing, legal reforms, prudential regulations, credit rating, and introducing a new mechanism to allow greater exchange rate flexibility. The financial sector was restructured and opened up to competition.

Prior to the adoption of the open-door policy in 1990, the financial system in Japan was characterized by a restricted flow of capital due to various regulations such as foreign exchange and foreign trade control laws, the foreign investment law, and the allocation of capital based on government policy rather than competitive market forces. A wide range of corporate governance reforms were carried out incrementally and numerous amendments made to the commercial codes and other related laws. 
These reforms paved the way for drastic changes and restructuring activities in the corporate sector. This led to an increase in the number of firms listed on the stock exchange: the average rose to 99 new firms per year during 1997-2004 compared to 36 per year during 1990-96 and only 26 per year between 1981 and 1989. Similarly, 41 firms were delisted per year from the stock exchange during 1997-2004 compared to just four or five firms per year during the 1980s and early 1990s.

Firms rapidly sought to restructure their organization, behavior, and financial choices. Decentralization in business decisions was introduced and financial choices that had been dominated by indirect borrowing shifted from the debt market to the capital market. These changes were closely associated with changes in corporate boards, such as the introduction of an executive officers system and greater separation of monitoring and management functions. Merger and acquisition transactions increased from 252 per year in 1991-97 to 1,381 annually in 1998-2005.

The corporate governance structure also changed drastically. The main bank system was institutionally displaced and its scope became more limited. Cross-shareholding-one of the main features of corporate governance structures in the pre-bubble burst period-decreased significantly and the scope and role of private individuals and foreign institutional investors rapidly increased. 